\title{
Contribution to the Flora of Hada Elsham Area, Western K.S.A, With special Reference to Their Uses
}

\author{
A. K. Elsafori \\ Department of Arid Land Agriculture, King Abdulaziz University, Jeddah, Saudi Arabia
}

\begin{abstract}
The present study has been conducted in Hada El Sham area, Western K.S. A. The study is mainly taxonomic that included collection, preparation, identification and classification of plant species in the study area. A total of 108 plant species were identified belonging to 32 families, and 74 genera, represent the flora of the study area. The study also included a survey of the uses of plant species of the area, where (89) species out of identified species were found to have economic importance. These represent (84\%), of the total plant species of the study area. The study reviewed the names of families and species according to recently published corrections, and found some were altered, so they were changed to recent names. It is recommended to conserve the plant species of the study area so as to reduce the encroachment of desertification and preserve the plant species of economic, and medicinal importance.
\end{abstract}

Keywords: Identification; Classification; Plant species; Medicinal values; Economical importance; and arid climates; Hada Elsham; K.S.A.

\section{(9) (i) CC BY: Creative Commons Attribution License 4.0}

\section{Introduction}

Vegetation cover of Saudi Arabia is divided into five broad categories. 1- Vegetation coastal plains and sabkhas. 2- Deserts and scarcely vegetated areas. 3- Dwarf shrub-lands. 4- Woodlands and xeromorphic shrub-lands of high altitude areas. 5- Wadi communities. Saudi Arabia a part of the Arabian Peninsula, covers more than 2 million square kilometers and comprises several distinct physiographical regions, such as mountains valleys, sandy and rocky deserts, salt pans and lava areas (Harrats). The overall climate of the country, except for Asir Province is classified as an arid province within Thornthwaite's global climatic classification [1]. The flora of Saudi Arabian consider the richest biodiversity in the Arabian Peninsula and comprises important genetic resources of crop and medicinal plants and xerophytic vegetation makes up the prominent features of the plant life in the kingdom. According to Collenette [2], the greatest species diversity in Saudi Arabia has occurred in Asir and Hijaz, the western mountainous area of the Kingdom, which borders the Red Sea which can be attributed to a greater rainfall and range of altitude from sea level up to $9,300 \mathrm{~m}$. Many previous studies showed that topography of the study area and climatic conditions are the main factors affecting the degree of speciation. The flora and vegetation cover of Saudi Arabia were extensively studied represented in the work of Collenette [2] and Chaudhary and Al-Jowaid [3], Migahid [4], and Al- Khamis, et al. [5], which may be regarded as the standard reference floras of the area. Vegetation of the western part of the country is diverse and dense. These areas mainly divided into coastal Tihama, foothills and escarpment. Wadis and foothills are sparsely vegetated, scattered populations of Acacia tortilis, Maerua crassifolia, Ficus palmata, Moringa peregrine and Ocharadenus baccatus, can be seen in areas. According to recent estimates [6], Saudi Arabia contains about 2253 species in 132 families, of which about 20\% are rare plants. The number of genera currently stands at 837. Among the families, 37 are represented by a single species. The south western region, from Taif to Yamen border contains about $70 \%$ of floristic elements of Saudi Arabia [6]. The main objectives of this study are to document the flora of Hada Elsham area, and consequently to contribute in updating the flora of K.S.A., and to document plant species with economic importance.

\section{Material and Methods}

The study was carried out at Hada Al-Sham $\left(21^{0} 48^{\prime} 3^{\prime \prime} \mathrm{N}, 39^{0} 43^{\prime} 25^{\prime \prime} \mathrm{E}\right)$, Jeddah, Saudi Arabia.

Climate of the study area; characterized by high temperature in summer and warm in winter. The study area has an arid climate and the rainfall apart from it is scantiness is irregular and variables.

The field trips were carried out to the study area for collecting the specimens. Plant specimens were collected fresh from the field, in two collection seasons during 2016 and 2017, from sites representing all the study area. The whole plant was collected in case of herbs and twigs with leaves and flowers and / or fruits in case of shrubs and trees. The specimens were stretched to dry between newspapers and firmly pressed inside herbarium press. Newspapers were continuously changed during the drying period to avoid rotting of material; finally the specimens were mounted, labeled and deposited at the laboratory of Agricultural Research Station of King Adulaziz University, Hdada Al-Sham. Observations were recorded, on the habit, habitat, distribution, color and liquid , during collection trips. 


\subsection{Species Identification}

In the laboratory, further analysis and / or identification were done, initially by examining the various parts of the specimens collected using hand- lens. Fine characters were examined under microscope for dissecting the flora parts. The identified specimens were compared with the identified floras by Collenette [2] and Chaudhary and AlJowaid [3], Al-Eisawi and Al-Ruzayza [7], Migahid [4], and Alsherif, et al. [8], in Saudi Arabia .

The families, genera, and species were all arranged in alphabetical order. Medicinal folkloric and other uses of the collected species have been provided. These uses have been extracted from available literature on Saudi Arabia plants and plants of neighboring countries [9], ELsafori [10], Adjanohoun, et al. [11], Al-Shanwani [12]. In addition, some information was obtained from the inhabitants of the study area.

\section{Results}

\subsection{The Flora}

The study reported (108) plant species at the study area. Belonging to 32 families (29 dicots. And 3 monocots). The plants of the study area have been updated ( names, genera and families). The results as follows:

Table-1. Flora of Hada Elsham area, Western Saudi Arabia

\begin{tabular}{|c|c|c|c|}
\hline Family & Species & Habit & Uses \\
\hline \multirow[t]{3}{*}{ Aizoaceae } & Trianthema portulacastrum L. & Pro. Herb & $\mathrm{M}$ \\
\hline & Sesavium verrucosum Raf. & Pro. Herb & $\mathrm{E}$ \\
\hline & Zalya pentandra (L.)Jeffrey & Herb & $\mathrm{M}$ \\
\hline \multirow[t]{6}{*}{ Amaranthaceae } & Aerva javanica (Burm.f.)Schultes & Herb & $\mathrm{M}$ \\
\hline & Amaranthus graecizans L. & Herb & $\mathrm{F}$ \\
\hline & Amaranthus lividus L. & Herb & $\mathrm{F}$ \\
\hline & Amaranthus hybridus L. & Herb & $\mathrm{F}$ \\
\hline & Digera muricata (L.) Mart. & Herb & - \\
\hline & Haloxylon persicum Bunge & Tree & S.D.Fi. \\
\hline Apocynaceae & Rhazya stricta Decene. & Herb & $\mathrm{M}$ \\
\hline Arecaceae(Palmae) & Phoenix dactylifera $\mathrm{L}$. & Tree & $\mathrm{E}$ \\
\hline Aristolochiaceae & Aristolochia bracteolate Lam. & Herb & $\mathrm{M}$ \\
\hline \multirow[t]{2}{*}{ Asclepiadaceae } & Caltropis procera (Ait)Ait.f. & Shrub & $\mathrm{M}$ \\
\hline & Leptadenia pyrotecnica (Forssk.)Dence. & Shrub & S.D.Fi. \\
\hline \multirow[t]{7}{*}{ Asteraceae(Compositae) } & Artemisis monosperma Del. & Bushy & $\mathrm{M}$ \\
\hline & Crepis sancta L. & Herb & - \\
\hline & Flaveria trinerva (Spreng.)Mohr. & Herb & - \\
\hline & Launea capitata (Spreng.)Dandy & Herb & $\mathrm{M}$ \\
\hline & Pulicaria crispa (Forssk.) Oliver. & Herb & $\mathrm{M}$ \\
\hline & Sonchus oleraceous L. & Herb & $\mathrm{M}$ \\
\hline & Sonchus tenerrims L. & Herb & $\mathrm{E}$ \\
\hline Balanitaceae & Balanites aegyptiaca (L.) Del. & Tree & $\mathrm{M}^{* * *}$ \\
\hline \multirow[t]{3}{*}{ Boraginaceae } & Heliotropium europaeum L & Herb & $\mathrm{F}$ \\
\hline & Heliotropium terocarpum L. & Herb & $\mathrm{F}$ \\
\hline & Trichdesma africanum (L.) R.Br & Herb & - \\
\hline \multirow[t]{4}{*}{ Brassicaceae(Cruciferae) } & Farsetia aegyptiaca Turra. & Herb & $\mathrm{F}$ \\
\hline & Harwoodia dicksoniae $\quad$ Turril. & Herb & - \\
\hline & Schimpera Arabica Hochst\&Steud. & Herb & - \\
\hline & Zilla spinosa Prentt & Herb & $\mathrm{F}$ \\
\hline \multirow[t]{6}{*}{ Cappariceae } & Capparis cartilaginea Decne. & Shrub & $\mathrm{M}^{* * *}$ \\
\hline & Capparis decidua (Forssk.)Edgew & Shrub & $\mathrm{M}^{* * *}$ \\
\hline & Capparis sandwicniana Dc & Shrub & - \\
\hline & Dipterygium glaucum Decne. & Herb & $\mathrm{M}$ \\
\hline & $\begin{array}{l}\text { Maerua } \\
\text { (Forssk.)Gilg\&Bendict }\end{array}$ & Tree & M \\
\hline & Maerua oblongifolia (Forssk.)A.Rich. & climber & $\mathrm{F}$ \\
\hline \multirow[t]{2}{*}{ Chenopodiaceae } & Halothamus boltae (Jaub.\&Spach)Moq. & Shrub & $\mathrm{F}$ \\
\hline & Salosa imbricate Forssk. & W. Shrub & $\mathrm{F}$ \\
\hline \multirow[t]{2}{*}{ Cleomaceae(Capparaceae } & Cleome gynandra L. & Herb & M*** \\
\hline & Cleome chrysantha Dence & Herb & - \\
\hline \multirow[t]{3}{*}{ Convolvulaceae } & Convolvulus arvensis L. & Climber & $\mathrm{F}$ \\
\hline & Convolvulus glomeratus Choisy & Trailing & - \\
\hline & Convolvulus pilosellifolius Desr. & Pro. Herb & - \\
\hline Cucurbitaceae & Citrulus colycynthis (L.)Shrad & Pro. Herb & $\mathrm{M}^{* * *}$ \\
\hline Cyperaceae & Cyperus rotundus L. & Herb & $\mathrm{M}^{* * *}$ \\
\hline
\end{tabular}


Journal of Agriculture and Crops

\begin{tabular}{|c|c|c|c|}
\hline Euphorbiaceae & Euphorbia aegyptiaca Bioss. & Herb & $\mathrm{M}$ \\
\hline & Euphorbia granulata Forssk. & Herb & - \\
\hline & Euphorbia helioscopia L. & Herb & $\mathrm{M}$ \\
\hline & Euphorbia hirta L. & Herb & $\mathrm{M}^{* * * *}$ \\
\hline & Jatropha glauca Vahl. & Shrub & $\mathrm{M}$ \\
\hline & Phyllanthus rotundifolia Willd & Herb & $\mathrm{M}$ \\
\hline & Ricinus communis L. & Shrub & $\mathrm{M}$ \\
\hline Fabaceae & Acacia ehrenbergiana (Forssk.)Hayne & Tree & M \\
\hline Sub.f.Mimosoideae & Acacia orerefota (Frossk.)Schweinf. & Shrub & $\mathrm{M}$ \\
\hline Sub.f.Mimosoideae & Acacia modesta Wall. & Tree & $\mathrm{F}$ \\
\hline Sub.f.Mimosoideae & Acacia tortilis (Forssk.)Hayne & Tree & $\mathrm{F}$ \\
\hline Sub.f.Mimosoideae & Acacia tortilis(Forssk.) subsp. raddina & Tree & $\mathrm{F}$ \\
\hline Sub.f.Faboideae & Indigofera oblongifolia Forssk. & Herb & - \\
\hline Sub.f.Faboideae & Indigofera hochsterri Bak. & Herb & - \\
\hline Sub.f.Faboideae & Indigofera spinosa Forssk. & Herb & - \\
\hline Sub.f.Mimosoideae & Prosopis juliflora (Sw.)Dc. & Tree & $\mathrm{F}$ \\
\hline Sub.f.Faboideae & Tephrosia nubica (Bioss.)Baker & Herb & M \\
\hline Sub.f.Faboideae & Tephrosia quartiniana Cufod. & Herb & $\mathrm{M}$ \\
\hline Sub.f.Faboideae & Tephrosia purpurea $(\mathrm{L}$.$) Pers.$ & Under shrub & $\mathrm{M}^{* * * *}$ \\
\hline Sub.f.Caesalpinioideae & Senna alexandrina Mill. & Herb & M \\
\hline Sub.f.Caesalpinioideae & Senna italic Mill. & Herb & $\mathrm{M}$ \\
\hline Lamiaceae (Labiateae) & Ocimmum basilicum $\mathrm{L}$. & Herb & $\mathrm{M}$ \\
\hline Liliaceae & Aloe vera (L.)Burm.f. & Herb & $\mathrm{M}^{* * * *}$ \\
\hline Malvaceae & Abutilon figarianum Webb. & Herb & $\mathrm{M}$ \\
\hline \multirow[t]{2}{*}{ Nyctaginaceae } & Boehervia erecta $\mathrm{L}$. & Herb & $\mathrm{M}^{* * * *}$ \\
\hline & Boehervia repens $\mathrm{L}$. & Herb & $\mathrm{M}^{* * *}$ \\
\hline Oleaceae & Olea europoea $\mathrm{L}$. & Tree & $\mathrm{M}$ \\
\hline \multirow[t]{18}{*}{ Poaceae (Graminae) } & Cenchrus ciliaris L. & Grass & $\mathrm{F}$ \\
\hline & Chloris gyagana Kunth. & Grass & $\mathrm{F}$ \\
\hline & Cynodon dactylon $(\mathrm{L}$.$) Pers.$ & Grass & $\mathrm{M}^{* * * *}$ \\
\hline & Dactylonium aegyptium (L.)Willd. & Grass & $\mathrm{F}$ \\
\hline & Digitaria absendens (Kunth.) Henrard & Grass & $\mathrm{F}$ \\
\hline & Echinochloa colonum (L.)Link & Grass & $\mathrm{F}$ \\
\hline & Eleusine indica (L.)Gaertn. & Grass & $\mathrm{F}$ \\
\hline & Eragrostis diplachnoides Steud. & Grass & $\mathrm{F}$ \\
\hline & Panicum lantoidate Retz. & Grass & $\mathrm{F}$ \\
\hline & Phalaris minor Retz. & Grass & $\mathrm{F}$ \\
\hline & Panicum turgidum Forssk. & Grass & $\mathrm{F}$ \\
\hline & Pennisetum divisum(Gmel.)Henr & Grass & $\mathrm{F}$ \\
\hline & Pennisetum setaceum (Forssk)Chiov. & Grass & $\mathrm{F}$ \\
\hline & Tragus racemosus (L.)All. & Grass & $\mathrm{F}$ \\
\hline & Setaria viridis (L.)P.Beauv. & Grass & $\mathrm{F}$ \\
\hline & Setaria verticillata(L.)P.Beauv. & Grass & M \\
\hline & Sporobolus minutus Link & Grass & $\mathrm{F}$ \\
\hline & $\begin{array}{|ll|}\text { Stipagrostis } & \text { hirtiglum( } \\
\text { Steud.ex.Trin)Dewinter } & \\
\end{array}$ & Grass & $\mathrm{F}$ \\
\hline \multirow[t]{2}{*}{ Portulacaceae } & Portulaca oleracea L. & Herb & $\mathrm{M}^{* * * *}$ \\
\hline & Portulaca quadrifida $\mathrm{L}$. & Herb & $\mathrm{M}^{* * * *}$ \\
\hline Resedaceae & Ochradens baccatus Del. & Shrub & $\mathrm{F}$ \\
\hline \multirow[t]{2}{*}{ Rhamnaceae } & Ziziphus spina-christi (L.)Desf. & Tree & $\mathrm{M}^{* * *}$ \\
\hline & Ziziphus spina-christi var.inermis & Tree & $E$ \\
\hline \multirow[t]{2}{*}{ Solanaceae } & Solanum nigrum L. & Herb & $\mathrm{M}^{* * *}$ \\
\hline & Wathania somnifera(L.)Dunal. & Herb & $\mathrm{M}$ \\
\hline Tamaricaceae & Tammarix aphylla $(\mathrm{L}$.$) Karst.$ & Tree & $\mathrm{F}$ \\
\hline \multirow[t]{3}{*}{ Tiliaceae } & Corchorus depresses Stocks. & Pro. Herb & $\mathrm{E}$ \\
\hline & Corchorus trilocularis L. & Herb & $\mathrm{E}$ \\
\hline & Grewia tenex $\mathrm{L}$. & Shrub & $\mathrm{M}$ \\
\hline Urticaceae & Forskoala tenacissima $\mathrm{L}$. & Herb & $\mathrm{M}$ \\
\hline \multirow[t]{4}{*}{ Zygophyllaceae } & Fagonia bruguieri & Herb & $\mathrm{M}$ \\
\hline & Fagonia cretica $L$. & Herb & $\mathrm{M}$ \\
\hline & Fagonia indica $\mathrm{L}$. & Herb & $\mathrm{M}$ \\
\hline & Fagonia paulyana J.Wagner\&Vierh & Herb & - \\
\hline
\end{tabular}




\begin{tabular}{l|l|l|l}
\hline & Peganum harmala L. & Herb & $\mathrm{M}$ \\
\hline & Tribulus bimucronatus Kralik & Pro. Herb & $\mathrm{M}$ \\
\hline & Tribulus terristris L. & Pro. Herb & $\mathrm{M}$ \\
\hline
\end{tabular}

M***: top powerful medicinal uses, M: medicinal uses, F: fodder uses., E: edible., S.D.F.: sand dunes fixation.

M***: powerful medicinal uses, M: medicinal uses, F: fodder uses, E: edible uses, S.D.F.: sand dunes fixation.

From the identified species of the present study (89) species out of the total number, were found have medicinal ,fodder and edible values, these represent $(84 \%)$, of the total flora. The number of species have medicinal values (51), fodder values (32) and edible values (6), respectively. The medicinal plants represent (48.1\%), fodder plants represent $(30.2 \%)$ and edible plants represent $(5,7 \%)$,of the total flora. Top 16 plant species of medicinal plants were found have powerful medicinal uses $\left(\mathbf{M}^{* * *}\right)$. The study revealed that among the herbaceous plants the use of grasses for medicinal purposes is very rare.

\section{Discussion}

The collection from the study area covered different habitats, and a total number of (106) plant species were studied. These species belong to (32) families (29) Dictoyledonous and 3 monocotyledonous). Most of the species of the study area were widely distributed in the country. The families were represented with a reasonable number of species, some with only one species, due to lack of suitable habitats. The study area is generally sparsely vegetated and has low species diversity. This may be attributed to rainfall fluctuations, sand rifts, overgrazing, and excessive use. The present study found similar findings to Chaudhary and Al-Jowaid [3] , and Collenette [2].

\section{Conclusion}

The most common dicotyledonous families were Fabaceae, and Euphorbiaceae, whereas the most important monocotyledonous family was poaceae. The most common dicotyledonous woody species were Acacia ehrenbergiana, Acacia tortilis subsp. raddiana and Maerua crassifoloia, whereas the herbaceous species were indigofera ssp., and Corchorus ssp. The most common monocotyledonous species were Dactyloctenium aegyptium, Setaria ssp., Cynodon dactylon, Eragrostis ssp., and Digera muricata.

The flowering plants of the study area were revised and updated, particularly names, genera and families . The Study explained that some names of families and species were altered. These were changed according to published corrections.The families changed were (Palmeae to Arecaceae, Compositeae to Asteraceae, Cruciferae to Brassicaceae, Labiateae to Lamiaceae, and Graminae to Poaceae).

The species changed were ( gynandropis gynandra to Cleome gynandra, and shifted from family Capparaceae to Cleomaceae , and Acacia nubica to Acacia oerfota).

\section{Recommendations}

From the above mentioned, the plants conservation, must be considered so as to reduce the encroachment of desertification, and to preserve plant species of economic importance and medicinal values. This is evident from field observations, meteorological data and personal communication with elderly people in the study area.

There is a need for reseeding of plant species . Management of these plants should conform to the ecological factors prevailing in the study area.

\section{References}

[1] Al-Nafie, A., 2008. "Phytogeography of Saudi Arabia." J. Bio. Sci., vol. 15, pp. 159-179.

[2] Collenette, S., 1998. Checklist Of botanical species in Saudi Arabia Internal asclepiad society. UK, pp. 180 .

[3] Chaudhary, S. A. and Al-Jowaid, A. A., 1999. "Vegetation of the kingdom of Saudi Arabia, Saudi Arabia."

[4] Migahid, A., 1988. "Flora of Saudi Arabia, Riyadh University, Riyadh, Saudi Arabia." vol. 1, p. 574.

[5] Al- Khamis, H. H., Al-Hemaid, F., and Ibrahim, A., 2012. "Diversity of perennial plants at Ibex reserve in Saudi Arabia." J. Animal Plant Science King Saud University Saudi Arabia, vol. 22, pp. 484-492.

[6] Sameer, H. Q., Ehab, A. K., and Khaled, S. A., 2016. "Pharmacy and allied sciences." International J. of Biology, vol. 5, pp. 2956-2966.

[7] Al-Eisawi, D. M. and Al-Ruzayza, S., 2015. "The flora of Mecca city, Saudi Arabia." I. J. Biod. Con., vol. 7, pp. 173-189.

[8] Alsherif, E. A., Ayesh, A. M., Allogmani, A. S., and Rawi, S. M., 2012. "Exploration of wild plants wealth with economic importance tolerant to difficult conditions in khulais Governorate, Saudi Arabia." Sci. Res. \& Essays, vol. 7, pp. 3903-3913.

[9] El-Ghazali, G., Al-Khalifa, Saleema, G., and Abudullah, E., 2010. "Traditional medicinal plants indigenous to Al-Rass province, Saudi Arabia." J. Med. Plants Res., vol. 4, pp. 2680-2683.

[10] ELsafori, A. K., 2006. "Eco- taxonomic study on the vegetation cover Of Umm Rimmtta Area, White Nile State, Sudan." Thesis Of Ph.D University of Khartoum, Sudan.

[11] Adjanohoun, J. E., Ahiyi, M. R. A., Assi, L. A., Alia, A. M., Amali, C. A., Kakooko, Z. O., Morakinyo, O., Mubira, N. K., Ogwal-Okengo, J. W., et al., 1993. Traditional medicine and pharmacopoeia, in Uganda (OAU/STRC). Lagos.

[12] Al-Shanwani, M., 1996. Plants used in Saudi Arabia falk medicine KACST. Riyadh. 